\title{
Analisis strategi humas pemerintahan era milenial dalam menghadapi tata kelola informasi publik
}

\author{
Aat Ruchiat Nugraha ${ }^{1}$, Diah Fatma Sjoraida ${ }^{2}$, Evi Novianti ${ }^{3}$ \\ ${ }_{1,2,3}$ Universitas Padjadjaran, Bandung, Indonesia
}

\begin{abstract}
ABSTRAK
Potensi peran humas pemerintah di era milenial sangatlah tinggi seiring dengan kemajuan teknologi informasi, iklim demokrasi yang terbangun, serta masyarakat yang semakin kritis. Mewujudkan lembaga Humas Pemerintahan yang memiliki tata kelola informasi yang baik dan adaptif terhadap perubahan zaman sangatlah tidak mudah. Terdapat peluang dan kendala untuk mewujudkan aparatur pelaksana Humas Pemerintahan yang profesional tergantung pada visi, misi, strategi dan taktik pimpinan dalam memberdayakan peran, fungsi, serta kewenangan lembaga kehumasan dalam mengelola informasi publik. Tujuan penelitian ini adalah untuk mengetahui unsur dan model mekanisme strategi humas pemerintahan di era milenial. Penelitian ini berdasarkan metode kualitatif deskriptif dengan teknik pengumpulan data penelitian dilakukan secara primer, yaitu wawancara pada informan yang menjabat sebagai pengelola aktivitas lembaga kehumasan tingkat pemerintahan pusat, provinsi, dan kabupaten/kota dan data sekunder melalui studi dokumentasi dan observasi non partisipatif. Hasil penelitian menunjukkan bahwa strategi humas pemerintah pada era milenial mengutamakan pada peningkatan aspek kolaborasi dari berbagai pemangku kepentingan melalui pemanfaatan platform media konvensional dan media digital guna mewujudkan layanan komunikasi dan informasi publik yang efektif dan berkualitas dalam mendukung tata kelola informasi publik yang terbuka. Simpulan penelitian menunjukkan bahwa penggunaan strategi pelibatan stakeholders, strategi pengemasan pesan narasi tunggal, strategi media konvensional, dan strategi media sosial dilakukan secara optimal dan terintegrasi dalam rangka mencapai transformasi lembaga kehumasan pemerintah yang dapat berperan aktif pada pengelolaan kebijakan komunikasi strategis pimpinan dan lembaga.
\end{abstract}

Kata-kata Kunci: Humas pemerintahan; strategi; teknologi; milenial; informasi publik

\section{Analysis of the millennial era government public relations strategy in dealing with public information governance}

\section{ABSTRACT}

The potential role of government's public relations is considered very high in the millennial era, as advances in information technology, a developed democratic climate, and an increasingly critical society play a vital role in transforming society. However, creating a Government Public Relations institution with good information governance and adaptive to a constantly changing environment is not easy. There are opportunities and obstacles to accomplish implementation by a professional public relations apparatus depending on the leadership's vision, mission, strategy, and tactics in empowering the roles, functions, and authorities of public relations institutions in managing public information. This study aimed to determine the elements and models of government public relations strategy mechanisms in the millennial era. This research is based on a descriptive qualitative method with research data collection techniques conducted primarily by interviews with informants who serve as managers of public relations institutions at the central, provincial, and district/ city levels and secondary data through non-participatory documentation and observation studies. The study results indicate that the government's public relations strategy in the millennial era prioritizes increasing the collaboration of various stakeholders through conventional media platforms and digital media to perform effectively and achieve service excellence on public information and communication services in supporting open public information governance. The study's conclusions indicate that the use of stakeholder engagement strategies, single narrative message packaging strategies, conventional media strategies, and social media strategies is carried out optimally. The integration work towards achieving the transformation of government public relations institutions plays an active role in managing strategic communication policies of leaders and institutions.

Keywords: Government public relations; strategy; technology; millennials; public information

Korespondensi: Aat Ruchiat Nugraha, S.Sos., M.Si. Universitas Padjadjaran, Jl. Raya Bandung Sumedang KM 21, Jatinangor 45363,Email: ruchiat@unpad.ac.id 


\section{PENDAHULUAN}

Informasi dan komunikasi kini telah menjadi bagian gaya hidup bagi masyarakat generasi milenial. Banyaknya informasi yang "berserakan" telah mendorong bagian pengelola informasi dan komunikasi yang kita sebut dengan istilah Humas untuk segera melakukan perubahan strategis baik secara personal maupun kelembagaan. Humas merupakan salah satu unsur yang penting dalam melakukan pelayanan informasi dan komunikasi bagi publiknya yang ada di suatu lembaga. Khususnya, keberadaan bagian humas pemerintahan selalu mendapatkan kesan yang negatif terkait peran, fungsi, dan perilakunya dalam melayani masyarakat. Untuk dapat "melepaskan" keterbelengguan akan kesan negatif tersebut, saat ini humas di lembaga pemerintahan melakukan revitalisasi dan tranformasi yang merupakan bagian dari reformasi birokrasi tata kelola kelembagaan humas yang dikeluarkan oleh Kementerian PAN dan RB. Tuntutan revitalisasi dan transformasi di bidang layanan informasi publik terkait dengan penerapan UU No. 14 Tahun 2008 tentang Keterbukaan Informasi Publik, yang di mana setiap lembaga yang dibiayai oleh negara maupun masyarakat harus dapat menyediakan berbagai data dan informasi yang dibutuhkan oleh masyarakat mengenai perencanaan, pelaksanaan, dan evaluasi program dan kebijakan yang dilakukan oleh suatu lembaga publik. Penekanan penyediaan informasi yang sesuai dengan tuntutan UU KIP telah diperkuat dengan penelitian yang menyebutkan dalam rangka menghadapi keterbukaan informasi publik, lembaga-lembaga pemerintah harus dapat mengoptimalkan peran sektor pelayanan komunikasi dan informasi publik pada lembaga kementerian dan lembaga pemerintah serta pemerintahan daerah (Suharyanti et al., 2012).

Dorongan reformasi birokrasi di lembaga humas pemerintahan dapat dilaksanakan dengan mengubah secara bertahap pada pola pikir aparatur pelaksana humas dalam hal budaya kerja. Berdasarkan hasil observasi dan data di lapangan menunjukkan bahwa lembaga humas pemerintahan masih jarang memiliki standar evaluasi dan pelaksanaan fungsi yang tepat dalam mengelola aktivitas kehumasan secara profesional. Hal ini akibat sistem birokrasi yang diterapkan bersifat terpusat, peran kebijakan pimpinan lembaga dan anggaran mengenai humas yang masih terbatas. Selain itu, dalam sistem, proses dan mekanisme kerja yang dilakukan oleh aparat pelaksana humas pemerintahan masih mengindikasikan pada aspek normatif kegiatan rutinitas pelayanan informasi dan komunikasi publik yang kurang sesuai dengan prinsip-prinsip good governance. Pola pikir kinerja humas pemerintahan masih seputar pelaksanaan kliping, pembuatan press 
release, konferensi pers, juru bicara pimpinan, dan pembuatan naskah pidato bagi pimpinan. Walaupun sering dianggap sebagai bidang pelengkap dalam kegiatan lembaga, namun dalam realitanya, saat ini humas memiliki peranan penting, terutama dalam membangun hubungan dan membentuk citra positif lembaga (Herdiana \& Khoiruddin, 2016).

Era milenial yang bersamaan dengan tuntutan keterbukaan informasi publik, menjadi titik tolak humas pemerintahan untuk dapat mengoptimalkan berbagai peran dan fungsinya menuju lembaga dan pranata humas profesional. Tugas pokok dan fungsi yang dilakukan oleh humas pemerintahan selama ini di antaranya sebagai juru bicara lembaga, fasilitator, penyedia informasi kebijakan, pelaksanaan program komunikasi, diseminasi informasi produk dan jasa lembaga, serta menciptakan iklim positif hubungan kelembagaan publik internaleksternal secara kondusif dan harmonis.

Mengingat tugas dan fungsi kehumasan yang strategis di bidang layanan informasi dan komunikasi serta banyaknya publik yang perlu dilayani dalam berbagai kepentingan, humas di lembaga pemerintahan dapat melakukan optimalisasi strategi komunikasi dalam menghadapi revolusi industri serta perkembangan teknologi komunikasi dan informasi yang mendukung tercapainya objektif organisasi. Strategi komunikasi merupakan kiat atau taktik yang bisa dilakukan dalam melaksanakan perencanaan komunikasi (Cangara, 2014). Hal lainnya tersirat dalam pernyataan Brown yang menyebutkan praktisi Humas pada abad ke-21, harus dapat memahami mekanisme kerja revolusi teknologi yang dapat mengendalikan dan mempengaruhi praktik kehumasan (Iriantara, 2019). Padahal, selama ini aspek budaya konvensional dalam praktik kehumasan dari praktisi komunikasi publik di lembaga pemerintahan yang konvensional begitu kuat yang berdampak pada gerak organisasi menjadi agak kaku. Selain itu, aspek budaya yang melekat pada kinerja humas yang "lambat" dalam memberikan pelayanan informasi dan bersifat monoton. Isu monoton kinerja humas pemerintahan ditanggapi dengan dilakukannya penataan budaya kerja melalui strategi percepatan reformasi birokrasi pada aspek penataan struktur birokrasi dan profesionalisasi PNS/ASN.

Strategikomunikasi sangat berperan penting untuk bisa membantu program kehumasan di lembaga pemerintahan agar lebih efektif. Sebab strategi komunikasi akan dapat membantu secara lebih efektif dalam mengembangkan hubungan, meningkatkan reputasi, dan membujuk orang untuk bertindak (Martinelli, 2012). Penggunaan strategi komunikasi di humas pemerintahan mempertimbangkan aspek lingkungan sosial, operasional, dan internal 
organisasi untuk dapat melahirkan strategi yang inovatif dalam menjawab tantangan era milenial yang berbasiskan pada teknologi informasi. Supaya dapat bertindak strategis, kegiatan kehumasan harus menyatu dengan visi dan misi organisasi (Gasing \& Suryanto, 2016). Sebelum era industri 4.0 strategi humas yang dilakukan oleh lembaga kehumasan pemerintahan masih konvensional (tradisional), yaitu mengutamakan diseminasi informasi publik dengan memanfaatkan media lini bawah (seperti spanduk, poster, baligo, flyer, dsb) dan media lini atas (seperti iklan layanan masyarakat di koran, majalah, radio dan televisi). Seiring perkembangan era milenial, strategi humas di lembaga pemerintahan pun mulai bergeser dari tradisional ke diseminasi informasi dan komunikasi publik yang melibatkan pada penggunaan platform online dan media sosial yang dapat menjangkau berbagai macam publik dan bersifat interaktif, ditandai dengan banyaknya bermunculan akun-akun resmi media sosial dan website lembaga pemerintahan (Kementerian/Lembaga/Daerah) sebagai sarana komunikasi yang bersifat modern (digital). Dengan kata lain, strategi humas saat ini mencerminkan pola yang muncul akibat disrupsi industri 4.0 (Meranti \& Irwansyah, 2018). Adanya perubahan strategi komunikasi humas pemerintahan dalam melaksanakan kegiatan kehumasan pada lembaga pemerintahan setidaknya akan berdampak pada budaya kerja. Menurut Grant, salah satu peranan penting suatu strategi adalah sebagai sarana koordinasi dan komunikasi dalam mengisi tujuan manajemen (Suherman, 2018).

Upaya optimalisasi pelaksanaan strategi humas di era digital pada lembaga pemerintahan, diperlukan sebuah langkah konkrit melalui reformasi birokrasi, revitalisasi dan transformasi humas untuk segera terwujud. Revitalisasi humas menyangkut pada upaya mengembalikan kembali sangat pentingnya peran humas pada suatu lembaga (state of being). Sedangkan transformasi humas menunjukkan pada aspek perubahan mendasar dan upaya mengubah kinerja humas pada suatu lembaga. Hal ini sebagaimana sesuai dengan pernyataan dari praktisi humas, Elizabeth Goenawan Ananto, menyebutkan bahwa orkestra penyampaian informasi dan komunikasi di antara lembaga pemerintahan perlu dibenahi dan dikonsolidasikan ulang untuk dapat mencapai peran dan fungsi komunikasi publik yang terintegrasi yang bukan hanya sebagai penyampai berita namun juga sebagai early warning system yang dapat mengdiagnosa permasalahan (Kartika, 2020).

Untuk dapat mencapai orkestra yang harmonis antara personal dan lembaga kehumasan di lembaga pemerintahan diperlukan suatupedoman penyelenggaraan aktivitas humas 
yang sama. Beberapa pedoman penyelenggaraan aktivitas humas pemerintah merujuk pada organisasi induk ASN yaitu Kementerian Pendayagunaan Aparatur Negara dan Reformasi Birokrasi (PAN-RB), Kementerian Komunikasi dan Informatika, Kementerian Dalam Negeri, dan lembaga pemerintahan lainnya. Salah satu dasar hukum yang menjadi rujukan dalam upaya revitalisasi dan transformasi Humas di lembaga pemerintahan yaitu pedoman umum penyelenggaraan aktivitas kehumasan yang dikeluarkan oleh Kementerian PAN dan RB yang meliputi pedoman umum audit komunikasi, pedoman umum pengelolaan krisis, pedoman umum komunikasi organisasi, pedoman umum tata kelola kehumasan, dan pedoman umum infrastruktur humas, pedoman umum pemetaan pemangku kepentingan, pedoman umum hubungan media, pedoman umum penulisan dan presentasi humas, dan pedoman umum pemanfaatan media sosial di lingkungan instansi pemerintah. Pedoman umum ini dijadikan sebagai rujukan untuk dapat melahirkan insan-insan praktisi humas pemerintahan yang profesional, berdaya guna, cerdas, adaptif, serta kreatif dalam rangka mewujudkan peranan humas sebagai komunikator, konselor, advisor, dan interpreter suatu lembaga yang kompeten.

Terlepas dari hasil capaian kerja yang dilakukan oleh humas lembaga pemerintahan berdasarkan program revitalisasi lembaga kehumasan di pemerintahan, maka seiring dengan aturan keterbukaan informasi publik melalui UU No. 14/2008, transformasi peran humas pemerintahan, secara organisatoris dihadapkan pada persoalan-persoalan internal kelembagaan baik yang menyangkut reformasi birokrasi dan transparansi akuntabilitas menuju clean governance. Selain itu, juga persoalan koordinasi serta komunikasi di antara humas pemerintahan dengan berbagai publik yang sangat beragam kepentingannya. Di tengah kondisi pandemi sekarang ini telah mengubah aspek pola komunikasi yang terjadi di masyarakat telah menjadikan posisi dan peran humas, khususnya di lembaga pemerintahan menjadi perlu untuk melakukan perubahan secara konstruktif dan tidak menyebabkan demotivasi bagi pranata humas. Kehadiran teknologi informasi dan komunikasi yang merambah pada pemanfaatan media komunikasi telah menyebabkan tergesernya "peranan" para pelaku humas di lembaga pemerintahan yang selama ini terbiasa dengan praktik berkomunikasi secara konvensional. Maka dari itu, diperlukan penyesuaian strategi, iklim dan kebiasaan kerja yang harus ditunjang oleh para pranata humas pemerintah untuk dapat menjelajahi era industri 4.0 secara bertahap agar tercapai suasana dan kinerja humas yang adaptif.

Bagi pelaksana atau penyelenggara 
pemerintahan terkait dengan era teknologi informasi ini, dituntut suatu keterbukaan atas penyelenggaraan negara, sehingga berjalan secara bersih dan berwibawa yang terbebas dari korupsi, kolusi, dan nepotisme (KKN). Maka dari itu, pada era serba digital, struktur dan mekanisme komunikasi pada suatu lembaga perlu secepatnya bertransformasi dari sifat kinerja konvensional menuju digital, termasuk lembaga pemerintahan. Sebab fungsi komunikasi dan penyebarluasan informasi mengenai layanan dasar masyarakat yang dilakukan oleh lembaga pemerintahan menjadi tugas yang sangat penting sebagai bagian dari tuntutan keterbukaan informasi publik. Atas tuntutan profesional layanan informasi dan komunikasi bagi masyarakat, maka humas lembaga pemerintahan membutuhkan suatu strategi komunikasi untuk dapat menjalankan aktivitasnya secara baik dalam rangka memperoleh kepercayaan masyarakat secara optimal.

Berdasarkan latar belakang di atas, maka saat ini humas di lembaga pemerintahan sedang menghadapi tantangan untuk dapat melakukan berbagai pengelolaan informasi dan komunikasi publik secara profesional dan proporsional. Sehingga diperlukan suatu kajian mengenai analisis strategi humas lembaga pemerintahan di era industri 4.0. Adapun tujuan penelitian ini adalah untuk menjelaskan dan menganalisis mengenai implementasi strategi komunikasi humas pemerintahan di era milenial dalam menghadapi tata kelola informasi publik yang semakin terbuka dengan kondisi masyarakat yang semakin kompleks dan kritis.

\section{METODE PENELITIAN}

Penelitian ini dilakukan di instansi pemerintah pusat, provinsi, dan kabupaten/kota dengan pendekatan kualitatif. Lokasi penelitian ini secara demografis berada di Provinsi DKI Jakarta dan Provinsi Jawa Barat dalam kurun waktu 2019-2021. Adapun instansi pemerintah yang dipilih pada tingkat pemerintahan pusat adalah lembaga humas yang terdapat di Kementerian kordinator Maritim dan Investasi, Kementerian Perhubungan, dan Kementerian Agama. Untuk tingkat instansi Lembaga Humas di level provinsi, yaitu Pemerintah Provinsi Jawa Barat, dan Lembaga Humas di tingkat kabupaten/kota diwakili oleh Humas Pemerintah Kabupaten Purwakarta dan Pemerintah Kota Cimahi. Untuk mendapatkan informasi tambahan mengenai praktik kehumasan di lembaga pemerintahan daerah, peneliti melakukan pengumpulan data juga pada instansi Dinas Komunikasi dan Informatika Provinsi Jawa Barat dan Komisi Informasi Daerah Jawa Barat.

Penelitian ini menggunakan metode kualitatif. Pemilihan metode penelitian 
Tabel 1 Pemilihan Objek Penelitian

\begin{tabular}{|c|c|c|}
\hline No & Lembaga & Keterangan \\
\hline 1 & $\begin{array}{lrr}\text { Biro } & \text { Komunikasi } & \text { Kementerian } \\
\text { Koordinator Maritim dan Investasi RI }\end{array}$ & $\begin{array}{l}\text { Institusi yang memiliki program inovatif selama } \\
\text { masa Pandemi Covid 19, penghargaan terpopuler } \\
\text { di media cetak } 2020 \text { pada Ajang PR Indonesia } \\
\text { Awards (PRIA), dan memperoleh predikat } \\
\text { berkategori Informatif dari Komisi Informasi } \\
\text { Pusat tahun 2021. }\end{array}$ \\
\hline 2 & $\begin{array}{l}\text { Biro Komunikasi dan Informasi } \\
\text { Publik Kementerian Perhubungan RI }\end{array}$ & $\begin{array}{l}\text { Memperoleh predikat berkategori Informatif dari } \\
\text { Komisi Informasi Pusat tahun } 2021\end{array}$ \\
\hline 3 & $\begin{array}{l}\text { Biro Humas, Data dan Informasi } \\
\text { Kementerian Agama RI }\end{array}$ & $\begin{array}{l}\text { Memperoleh predikat berkategori Menuju } \\
\text { Informatif dari Komisi Informasi Pusat tahun } \\
2021\end{array}$ \\
\hline 4 & $\begin{array}{l}\text { Biro Humas dan Protokol Pemprov } \\
\text { Jawa Barat }\end{array}$ & $\begin{array}{l}\text { Memiliki penghargaan dalam Public Relations } \\
\text { Indonesia Award (PRIA) } 2020 \text { kategori Humas } \\
\text { Pemerintah, Majalah Pemerintahan Daring, Sub } \\
\text { Kategori Pra Krisis, Majalah Pemerintahan Cetak, } \\
\text { dan Humas Paling Populer di Media Mainstream. }\end{array}$ \\
\hline 5 & Bagian Humas Pemkab Purwakarta & $\begin{array}{l}\text { Menerima penghargaan sebagai kabupaten } \\
\text { terpopuler di media digital dalam Anugerah } \\
\text { Humas Indonesia tahun } 2021 \text {. }\end{array}$ \\
\hline 6 & Bagian Humas Pemkot Cimahi & $\begin{array}{l}\text { Menerima penghargaan di tingkat nasional dari } \\
\text { Kemendagri sebagai salah satu dari } 10 \text { kota } \\
\text { dengan Kinerja Tertinggi tahun } 2019 \text {. }\end{array}$ \\
\hline
\end{tabular}

Sumber: Hasil Penelitian, 2019-2021

kualitatif ini merupakan perwujudan asumsi dasar yang penulis yakini berdasarkan teoritis yang dianut. Yang dimaksud dengan penelitian kualitatif berdasarkan beberapa ahli adalah penelitian yang mencoba memahami fenomena dalam situasi dan konteks naturalnya (bukan di laboratorium), yakni peneliti tidak berupaya untuk mengelabui fenomena yang sedang diamati (Sarosa, 2017); berlandaskan pada filsafat pospositivisme, interpretif, konstruktif yang digunakan untuk meneliti pada kondisi objek alamiah (Sugiyono \& Lestari, 2021). Dalam penelitian komunikasi kualitatif, analisis data dapat dilakukan saat pengumpulan data dan atau setelah proses pengumpulan data berakhir (Pujileksono, 2016). Jenis studi yang digunakan dalam penelitian kualitatif ini adalah deskriptif. Penelitian deskriptif bertujuan untuk membuat deskripsi secara sistematis, faktual, dan akurat mengenai fakta dan sifat populasi atau daerah tertentu melalui penggambaran mekanisme sebuah proses (Muhajirin \& Panorama, 2017). Adapun situasi yang tergambar mengenai aktifitas Humas Lembaga Pemerintahan, salah satunya pada proses adaptasi kegiatan humas dengan strategi komunikasi di era milenial.

Untuk teknik pengumpulan data primer dalam penelitian ini dilakukan melalui 
pengamatan lapangan, wawancara, dan diskusi dengan para pimpinan dan staf pranata humas di setiap lembaga pemerintahan pada tingkat pusat $(\mathrm{K} / \mathrm{L})$, provinsi, dan kabupaten/ kota serta stakeholders lainnya. Informan penelitian ini adalah para pimpinan dan staf humas di setiap lembaga pemerintahan di tingkat pusat, provinsi, dan kabupaten/kota dengan teknik sampel yang digunakan adalah purposif yang diperkirakan dapat mewakili populasi penelitian dan disesuaikan dengan kebutuhan data penelitian. Sumber data yang digunakan dalam penelitian ini berupa data primer yang berasal dari observasi terhadap kegiatan kehumasan yang ada di lingkungan pemerintahan pusat, provinsi, dan kabupaten/ kota dan kegiatan wawancara dengan para pimpinan Biro Komunikasi dan Informasi Publik atau Bagian Humas Pemerintahan. Data sekunder diperoleh dari dokumen yang terkait dengan penelitian ini, serta literatur-literatur yang berkaitan dengan masalah penelitian mengenai government public relations.

Dalam rangka menjaga kualitas informan, peneliti mengambil orang-orang yang benarbenar terpilih berdasarkan ciri kompetensi dan pengalaman di bidang kehumasan pada lembaga pemerintahan pusat, provinsi, dan kabupaten/ kota. Agar data penelitian kualitatif dapat dipertanggungjawabkan sebagai penelitian ilmiah maka perlu diadakan uji keabsahan data
(Siddiq \& Choiri, 2019). Pengujian keabsahan data penelitian kualitatif bisa dengan cara credibility (validitas internal), transferability (validitas eksternal), dependability (reliabilitas), dan confirmability (objektivitas). Adapun uji validitas dalam penelitian ini menggunakan tipe kredibilitas data melalui perpanjangan pengamatan dan peningkatan ketekunan dalam penelitian di lingkungan lembaga humas pemerintahan. Realibilitas dalam penelitian kualitatif bersifat majemuk, dinamis, sehingga tidak ada yang konsisten dan berulang seperti semula. Artinya reliabilitas dalam penelitian ini didapatkan dengan cara terus menerus mengamati perilaku dan aktivitas humas pemerintahan yang ada di tingkat pusat, provinsi, dan kabupaten/kota yang terpilih.

Teknik analisis data penelitian ini dilakukan dengan menggunakan analisis sebelum di lapangan yang tercermin dalam identifikasi/ fokus masalah penelitian. Selanjutnya dilakukan analisis selama di lapangan dengan menggunakan model Miles dan Huberman yaitu data reduction, data display, dan consclusion drawing/verification yang diterjemahkan oleh peneliti dengan melakukan wawancara berdasarkan pedoman wawancara yang dibuat dan dianalisis sampai mencapai tingkat kejenuhan data dan diperoleh data yang dianggap kredibel. 


\section{HASIL DAN PEMBAHASAN}

Kunci untuk pengembangan ke arah peranan praktisi kehumasan dan pencapaian profesionalisme di lembaga kehumasan dapat dilihat dari faktor internal (kekuatan \& kelemahan) humas, khususnya di lembaga pemerintahan $(\mathrm{K} / \mathrm{L})$ dalam menghadapi perkembangan teknologi informasi dan komunikasi era industri 4.0. Seorang profesionalitas Humas di lembaga pemerintahan harus beradaptasi dengan perilaku kehidupan generasi milenial yang aktif terhubung dengan internet dan media sosial sebagai kanal informasi sehari-hari. Generasi milenial dicirikan dimana teknologi informasi menjadi hal yang utama dan mempengaruhi segala aspek yang mengutamakan bentuk informasi dan komunikasi digital (Pohan, 2019). Kebiasaan gaya hidup generasi milenial biasanya selalu terhubung dengan smartphone, melakukan transaksi ekonomi noncash, serba instan dan cepat, fokus pada pengalaman, memiliki grup di dunia maya, talenta lebih dari satu, dan aktif berbagi informasi di dunia virtual(media sosial). Merujuk pada ciri yang dimiliki oleh generasi milenial, seyogyanya Humas di lembaga pemerintahan harus lebih pro aktif dan kreatif dalam mengalirkan informasi ke masyarakat dengan berbasiskan online. Artinya berbagai jenis informasi disampaikan secara cepat melalui platform media sosial yang terdapat dalam smartphone dalam rangka mendapatkan feedback secara cepat dari masyarakat.

Pemerintah selaku pemilik informasi kebijakan yang menyangkut hajat hidup orang banyak, harus dapat mendesiminasikan informasi publik secara offline maupun online. Sebab penyampaian informasi, baik online maupun offline membutuhkan kerangka acuan, pengetahuan, dan pengalaman di bidang kehumasan dalam meningkatkan pengelolaan komunikasi digital yang informatif dan dialogis serta mampu menjalin hubungan baik dengan publik untuk mewujudkan transparansi dan akuntabilitas informasi (Azhary, 2020). Mengimbangikompetensi perkembanganzaman milenial yang berbasiskan pada kemampuan melek teknologi informasi dan komunikasi, Humas di lembaga pemerintahan memiliki beberapa kekuatan dan kelemahan sebagai bagian dari dampak lahirnya revolusi industri 4.0. Berdasarkan hasil pengamatan, kekuatan humas pemerintahan di era revolusi industri 4.0 di antaranya memiliki pedoman kebijakan pelaksanaan kegiatan komunikasi dan informasi yang sama dari tingkat pusat hingga daerah, memiliki jaringan kelembagaan informasi dan komunikasi sampai pada tingkat pemerintahan yang paling rendah (RT/RW) dan Kelompok Informasi Masyarakat (KIM), dan memiliki sumber daya manusia (PNS/ASN/Pranata 
Humas) yang cukup banyak dan tergabung pada asosiasi profesi humas pemerintahan. Sebagai sebuah kekuatan, hal diatas dapat dijadikan sebagai peluang dasar revitalisasi, reformasi dan transformasi tata kelola lembaga kehumasan agar menjadi excellent dalam memenuhi kepuasan masyarakat di bidang layanan informasi dan komunikasi publik. Peningkatan kualitas pelayanan ini mengandung makna adanya upaya terhadap perubahan mutu dan kondisi dari keadaan "konvensional" menuju mutu "dinamis" dari perkembangan situasi dan kondisi masyarakat (Sahlan et al., 2016). Kekuatan yang ada di lembaga humas pemerintahan dalam hal diseminasi informasi ini, sesuai dengan pernyataan dari Hartanto selaku Kepala Bagian Publikasi dan Informasi Publik BKIP Kementerian Perhubungan menyatakan bahwa:
"Dalam melakukan kegiatan kehumasannya, potret humas $\mathrm{K} / \mathrm{L}$, khususnya Kemenhub melibatkan publik, mendengarkan aspirasi mereka, mampu menjawab kebingungan mereka, sehingga terbentuk reputasi positif yang kemudian menumbuhkan kepercayaan dan dukungan bahkan perubahan perilaku melalui penggunaan kanal komunikasi formal dan informal dengan menampilkan sosok juru bicara kredibel dan diterima publik".

Menurut Khairul Hidayati selaku Kepala Bagian Humas Biro Komunikasi Kemenko Maritim dan Investasi yang menyebutkan bahwa:

"Kekuatan yang ada dalam lembaga humas pemerintahan dalam menyebarkan informasi dilakukan dengan cara sosialisasi dan membangun narasi kebijakan yang sesuai dengan substansi khas kelembagaan..."

Hal yang serupa disampaikan oleh Dodo selaku pranata humas bagian Hubungan Kelembagaan Biro Humas, Data dan Informasi Kementerian Agama mengatakan bahwa:

"Dikarenakan target khalayak Kemenag yang cukup sensitif terkait persoalan nilainilai keagamaan, maka upaya diseminasi informasi dilakukan dengan pendekatan penyeragaman konten yang disesuaikan dengan ajaran agama masing-masing yang disampaikan oleh para penyuluh agama di tingkat daerah".

Pernyataan di atas sesuai dengan penelitian yang menyebutkan bahwa humas pemerintah lebih mengedepankan melakukan peran kemanajerialan yang sesuai tuntutan demokratisasi dan paradigma good governance dalam pelayanan prima bagi publik (Kriyantono, 2018). Kondisi tersebut menjadi dasar pemikiran bagi humas pemerintahan mengenai publik yang mempunyai hak untuk mengetahui informasi dan evaluasi kebutuhan lembaga kehumasan untuk memperoleh masukan dari publik. Melalui pendekatan komunikasi dialogis, humas di lembaga pemerintahan dapat menjadikan unsurpesan yang awalnya informatif menjadi persuasif, edukatif, dan partisipatif dalam rangka membangun dan meningkatkan kepercayaan dan kepuasan publik atas program dan kebijakan yang dilakukan oleh pemerintah. 
Meskipun humas merupakan salah satu metode komunikasi yang sangat diandalkan oleh suatu lembaga, namun secara peran dan fungsi kadangkala memiliki keterbatasan. Sementara itu, beberapa keterbatasan yang dimiliki oleh humas pemerintahan di era revolusi industri 4.0 adalah keberadaan SDM di bidang Humas (komunikasi publik) yang sedikit sesuai dengan kompetensi yang berasal dari kualifikasi ilmu komunikasi maupun kehumasan, operasional infrastruktur teknologi informasi dan komunikasi yang terbatas oleh anggaran, dan pelaksanaan kebijakan mengenai tugas, fungsi, dan posisi humas pemerintahan yang berbedabeda di setiap kelembagaan pemerintahan.

Keterbatasan ini dapat menjadi permasalahan tersendiri bagi tata kelola kehumasan pemerintahan yang menuju profesional. Kondisi seperti ini dapat dilihat dari pernyataan Niken Sitalaksmi Widjaja selaku Kepala Subbagian Perencanaan dan Strategi Komunikasi BKIP Kemenhub menyebutkan bahwa:

"Hierarki pengambilan keputusan berlapis, belum ada survei persepsi publik, evaluasi, dan audit komunikasi secara komprehensif dalam pengelolaan komunikasi publik di Kemenhub, serta terbatasnya SDM ASN dengan keahlian khusus (desain grafis, jurnalistik, konten kreator, dsb) menjadi permasalahan yang cukup serius di lembaga kami”.

Melalui pembenahan sistem kehumasan pemerintahan dengan melihat aspek kelemahan tersebut di atas tidak hanya pada tataran kompetensi kerja, tetapi juga harus memperhatikan aspek lainnya yaitu visi, misi, tujuan, sasaran action plan, tugas, fungsi, kedudukan dan peranan, serta kelembagaan, SDM, dan sarana dan prasarana implementasi komunikasi publik. Melihat akan kondisi tersebut, peningkatan kualitas serta kompetensi praktisi Humas ditengah kompleksitas permasalahan yang dihadapi lembaga pemerintahan saat ini harus segera terpecahkan yang didukung dengan kompetensi baru public relations yaitu harus memiliki kemampuan sebagai data analysis, social media management, influencer dan content creator (Arief \& Saputra, 2019) dan adaptasi budaya dalam praktik PR di Indonesia (Hartini, 2019). Dengan demikian, bukan hanya kompetensi yang tersirat saja yang dibutuhkan melainkan juga pada aspek kombinasi unik antara intuisi, nalar, empati, emosi serta kreativitas yang tidak terbatas (limitless) bagi praktisi kehumasan (Inspirasi, 2019) untuk dapat keluar dari keterbatasan aktifitas humas yang selama ini telah "mengikatnya" cukup lama.

Adanya kemajuan teknologi informasi dan komunikasi (information and communication technology/ICT) telah membawa perubahan pemikiran di sektor bisnis dan perekonomian global. Lahir dan terus berkembangnya ICT yang menjadikan kehidupan manusia lebih 
dipermudah melalui koneksi antarwilayah yang tidak dibatasi oleh ruang dan waktu secara cepat. Menanggapi kondisi ini, kalangan profesional maupun praktisi humas dalam menghadapi persaingan di era milenial melakukan langkah-langkah inovasi untuk menghindari "kebinasaan". Sehingga faktor eksternal (peluang \& ancaman) yang terdapat pada Humas di lembaga pemerintahan $(\mathrm{K} / \mathrm{L})$ dalam menghadapi perkembangan teknologi informasi dan komunikasi era industri 4.0 bagi profesi atau praktisi komunikasi publik/humas harus cekatan dalam menanggapi kemajuan teknologi, borderless communication and information, dan arus lalu lintas aliran arus informasi dan sumber daya lainnya yang dapat mempengaruhi layanan informasi dan profesi kehumasan. Maka dari itu, seorang profesional Humas harus dapat menemukan relevansinya dan terus mengikuti perubahan gaya hidup publik sasarannya. Melalui pelaksanaan sertifikasi profesi di bidang kehumasan yang sedang diupayakan oleh berbagai kelembagaan baik Asosiasi Profesi, Lembaga Pemerintah (Kemkominfo/BNSP) dan Perguruan Tinggi telah menciptakan infrastruktur untuk menjadi alat, agar profesional humas tetap berada di garis depan kegiatan komunikasi publik. Sehingga pada dasarnya peran humas di lembaga pemerintahan adalah menyosialisasikan pesan positif dan prestasi kepada publik agar terbangun kepercayaan dan reputasi lembaga (Inspirasi, 2019).

Adanya teknologi digital, suatu lembaga mampu meningkatkan produksi, distribusi, dan operasional secara signifikan, yang mengakibatkan peningkatan masif terhadap kualitas dan produktivitas keseluruhan. Namun, dalam rangka mengoptimalkan hal itu, dukungan dan bantuan dari para profesional diperlukan, termasuk profesional komunikasi atau humas. Profesional Humas yang identik dengan kompetensi hospitality perlu menguasai pengetahuan dan keterampilan yang multitalenta dalam rangka mengambil peran strategis pada era digital untuk mendapatkan kepercayaan publik. Berdasarkan penelusuran lapangan menunjukkan bahwa faktor peluang yang berasal dari luar organisasi Humas di lembaga pemerintahan di antaranya SDM Humas yang memiliki akun media sosial yang berbeda-beda, mempunyaifollower per akun nya relatifbanyak, dan postingan narasi program pembangunan dan kinerja lembaga yang bersifat positif. Sedangkan ancamannya adalah teknologi digital yang dapat "menggantikan" peran dan fungsi kinerja lembaga Humas yang bersifat offline menjadi online, tidak membutuhkan SDM yang banyak, dan nilai-nilai human relations yang akan segera "punah".

Faktor peluang dan ancaman perlu mendapatkan perhatian serius dari para aparat 
pelaksana humas pemerintahan sebab pada dasarnya humas di lembaga pemerintahan memiliki tugas menjadi garda terdepan sebagai sumber informasi bagi masyarakat dan kemampuan untuk meningkatkan kinerjanya membangun reputasi dan kepercayaan publik. Sejalan dengan perkembangan era revolusi teknologi informasi, saat ini telah terjadi perubahan pada peran, fungsi, dan tugas kehumasan sebagaimana terdapat beberapa tingkatan kegiatan humas dalam menyikapi kemajuan ICT yaitu: Humas 1.0 menjalankan kegiatan kehumasannya masih bersifat tradisional yang dimana PR sebagai broadcaster, Humas 2.0 menggambarkan komunikasi yang horisontal, saling berhubungan, komunikasi dari banyak sumber ke banyak audiens yang dimana humas berperan sebagai connector, Humas 3.0 di mana media sosial menjadi media yang paling banyak digunakan, disukai, dan dipercayai publik, dan Humas 4.0 di mana era artificial intelligence dan era big data hadir yang dapat menunjang pekerjaan humas secara robotik (Arief, 2019).

Pada era industri 4.0 ini, Humas di lembaga pemerintahan akan selalu menghadapi terpaan informasi yang viral dan serba cepat melalui sistem komunikasi media sosial dan big data yang tidak terbatas. Namun, efek keterbatasan yang dapat dimanfaatkan oleh humas bahwa kekuatan media akan cenderung mengadvokasi komunikasi antarpribadi dan pada akhirnya untuk mengantarkan khalayak untuk berbuat suatu tindakan komunikasi yang sesuai dengan strategi komunikasi/humas lembaga.

Strategi humas yang terbentuk di lembaga pemerintahan terkait dengan pemenuhan kebutuhan kepentingan keragaman publik di era industri 4.0merupakanupaya untukmemperjelas keberadaan profesi Humas Pemerintah yang sekarang ini terus mengalami perkembangan yang sangat pesat akibat tuntutan dan ekspektasi publik akan hak atas informasi (people right to know) dan meningkatnya kebutuhan akan sumber daya manusia yang profesional di bidang kehumasan pemerintah (Government Public Relations/GPR) melalui rekruitmen tenaga humas pemerintah (THP) sejak 2017. Hal ini sesuai dari hasil penelitian yang menyebutkan bahwa GPR di Indonesia dibangun secara simetris dalam jaringan, idealis atau kritis sebagai bagian dari kompetensi individual dan kinerja manajerial (Sugiyanto et al., 2016). Selain itu, GPR profesional di Indonesia juga didukung oleh adanya peraturan dan kebijakan pemerintah untuk menghasilkan para GPR yang lebih profesional. Berdasarkan aspek aturan pelaksanaan tugas GPR tercantum dalam Pasal 28F UUD 1945, UU Nomor 14 Tahun 2008 tentang Keterbukaan Informasi Publik, dan PermenPAN Nomor: 30 Tahun 2011 tentang Pedoman Umum Tata Kelola Kehumasan 
di Lingkungan Instansi Pemerintah. Artinya berdasarkan aturan tersebut, Humas harus mampu membangun kepercayaan masyarakat untuk mendukung pemerintah melalui berbagai inisiatif kehumasan.

GPR atau sering disebut dengan pranata Humas adalah pekerjaan yang bersifat fungsional yang dilakukan oleh seorang PNS/ASN yang diberi tugas, tanggung jawab, wewenang dan hak secara penuh oleh pejabat yang berwenang untuk melakukan kegiatan informasi dan kehumasan. Secara umum tugas pranata humas di lembaga pemerintahan adalah melakukan kegiatan pelayanan informasi dan kehumasan, meliputi: perencanaan pelayanan informasi dan kehumasan, pelaksanaan hubungan kelembagaan, pelaksanaan hubungan personil; dan pengembangan pelayanan informasi dan kehumasan. Sementara itu, menurut Wilcox et al., menyatakan bahwa ciri kegiatan kehumasan adalah disengaja, direncanakan (terorganisir), berkinerja (didasarkan kinerja organisasi induk), mengutamakan kepentingan umum. Hal ini memperkuat gagasan bahwa humas harus bermanfaat bagi organisasi dan masyarakat umum (Theaker, 2004). Kondisi ini sejalan dengan pemerintah sebagai pelaksana pembangunan dan pengambil kebijakan yang membutuhkan corong dalam penyampaian informasi mengenai capaian dan kinerja kepada publik sasarannya. Selain itu juga, posisi masyarakat sebagai objek yang menikmati pembangunan dan pelaksana kebijakan juga harus mengetahui sumber informasi yang tepat dan terbuka sebagai implementasi kausalitas adanya Undang-undang Keterbukaan Informasi Publik (KIP) antara lembaga pemerintahan dengan masyarakat atau sebaliknya.

Berdasarkan Undang-Undang Nomor 14 Tahun 2008 tentang Keterbukaan Informasi Publik(KIP)meletakkanparadigmabarubagitata kelola kehumasan pemerintah seiring tuntutan penyelenggaraan pemerintahan yang mengarah pada good governance. Dimensi keterbukaan, mudah akses, akuntabel dan transparan menjadi tuntutan utama penyelenggaran pelayanan kehumasan pemerintah. Untuk membangun pemerintahan yang sehat dan bersih dibutuhkan kritikan dan pendapat publik. Masyarakat dijamin haknya secara bebas untuk memperoleh informasi atas penyelenggaraan pemerintahan dan pemerintah berkewajiban menyediakan informasi yang dibutuhkan masyarakat. Komunikasi dua arah yang efektif akan menepis tindakan dan prasangka negatif masyarakat terhadap pemerintah. Ketangkasan humas dalam menyerap informasi dan aspirasi publik sebagai bagian masukan bagi pimpinan instansi pemerintah akan menjadi kerangka dukungan keberpihakan lembaga kepada kepentingan publik. Disini humas tidak saja tampil sebagai lembaga yang membangun citra positif tetapi 
lebih dari itu memberi andil dalam menciptakan penyelenggaraan sistem pemerintahan yang transparan dan populis.

Dalam menangani informasi bagi masyarakat, humas pemerintahan menghadapi berbagai kalangan pihak media dengan tampil sebagai pengemban informasi bagi kemajuan bangsa. Sebagai pengembang komunikasi lembaga pemerintahan, humas perlu mengupdate berbagai informasi. Selain itu, tugas humas lembaga pemerintahan yang menyampaikan seputar informasi masalah profesionalisme PNS/ASN) dan persoalan kedinasan yang perlu dijelaskan ke masyarakat dengan tujuan agar tidak menimbulkan resisten dan kegaduhan di masyarakat.

Sebagai bagian dari koalisi dominan yang terbentuk, Humas di lembaga pemerintahan memiliki permasalahan tersendiri seiring dengan mulai adanya jabatan yang terkait dengan pelayanan informasi, yaitu Pejabat Pelayanan Informasi \& Dokumentasi (PPID) di setiap dinas/badan yang ada di lingkungan kementerian/lembaga maupun dinas di tingkat provinsi/kabupaten/kota. Era keterbukaan informasi publik yang ditunjang dengan kemajuan ICT telah memberikan suatu terobosan agar SDM Humas di lembaga pemerintahan memiliki keleluasaan yang lebih dalam pengelolaan informasi dan komunkasi. Dalam upaya mewujudkan humas yang profesional di bidangnya, maka diperlukan sebuah strategi yang menjadi pedoman meraih visi dan misi lembaga pemerintahan agar dapat menjadi lembaga yang kredibel.

Untuk mengatasi keterbatasan aktifitas kehumasan di lembaga pemerintahan, humas pemerintah mengimplementasikan alternatif strategi yang biasa dilakukan dalam kegiatan komunikasi publik dengan masyarakat diantaranya strategi pelibatan stakeholders, strategi membangun story telling, strategi pemanfaatan media konvensional, dan media sosial. Terkait dengan penggunaan strategi komunikasi publik oleh Humas di lembaga pemerintahan disampaikan oleh informan diantaranya:

Khairul Hidayati selaku Kepala Bagian Humas Biro Komunikasi Kementerian Koordinator Maritim dan Investasi yang menyebutkan bahwa:

"Sebagai lembaga yang mengkoordinasikan kinerja kementerian teknis, Humas di kami (Kemenko Marves) memanfaatkan strategi agenda setting pada media konvensional (konferensi pers, wawancara pers, dsb) dan media sosial (adanya akun resmi media sosial) untuk dapat menjelaskan informasi maupun isu nasional yang ditangani oleh Kemenko Marves".

Selanjutnya, Niken Sitalaksmi Widjaja selaku Kepala Subbagian Rencana dan Komunikasi Publik Biro Komunikasi dan Informasi Publik Kementerian Perhubungan menyatakan bahwa strategi komunikasi publik 
yang saat ini digunakan adalah:

"Strategi story tellling dan narasi tunggal menjadi andalan kami (Kemenhub) untuk mensosialisasikan informasi di masa pandemi, khususnya disaat moment perayaan Hari Besar Keagamaan yang berkaitan dengan pengunaan kendaraan pribadi dan umum untuk mudik".

Informan lainnya, Khoeron selaku Kasubbag Peliputan dan Media Biro Humas, Data dan Informasi Kementerian Agama menyebutkan bahwa:

"Untuk melaksanakan kegiatan komunikasi publik, biasanya kami menggunakan strategi pelibatan stakeholders (tokoh agama dan penyuluh agama). Hal ini dikarenakan urusan agama itu sangat berpotensi melahirkan konflik. Sehingga kamimemerlukan pendekatan penyampaian informasi yang tidak menyinggung keyakinan salah satu umat beragama di Indonesia”.

Sedangkan bagi Biro Humas dan Keprotokolan Setda Provinsi Jawa Barat, Akhmad Taufiqurrachman selaku Kepala Subbagian Pelayanan Informasi mengatakan bahwa:

"Strategi komunikasi publik yang digunakan saat ini (era pandemi Covid-19) lebih menitikberatkan pada pemanfaatan platform digital, seperti aplikasi Pikobar, selain konferensi pers. Selain itu, strategi media sosial sering digunakan dengan tujuan untuk meraih reachment saat menyampaikan informasi dan menjalin hubungan dengan media mainstream".

Sementara itu, Yus Djunaedi Rusli selaku Kepala Bidang Aplikasi dan Telematika Diskominfo Purwakarta, bagi Bagian Humas
Pemkab Purwakarta, terkait penggunaan strategi komunikasi publik yang dilakukan dalam mendiseminasikan informasi publik menyebutkan bahwa:

"Humas dan Dinas Kominfo bekerjasama melakukan pelayanan informasi baik konvensional maupun digital, terutama kini kami sudah memanfaatkan aplikasi Call Center 112 dan Command Center Ogan Lopian sebagai sarana interaksi dengan masyarakat. Adanya aplikasi berupa media sosial telah membantu penyebaran informasi dan publikasi mengenai hasilhasil pembangunan dan event-event yang ada di kabupaten Purwakarta ke seluruh daerah tidak hanya di Purwakarta saja tetapi sampai ke pelosok negeri bahkan mancanegara".

Menurut Fithriandhy Kurniawan selaku

Kepala Bidang Informasi, Komunikasi Publik, dan Statistik pada Bagian Humas dan Protokol

Pemkot Cimahi menyebutkan bahwa:

"Strategi komunikasi publik yang sering kami lakukan adalah melibatkan stakeholders, pengunaan press release, konferensi pers, wawancara pers, dan menjalin hubungan baik dengan pihak wartawan sebagai bagian dari implementasi kemitraan penthahelix".

Peran Humas di lembaga pemerintahan sangat penting dalam mengantisipasi dan mengatasi persoalan penyebaran informasi yang menjadi bagian dari pelayanan dasar publik. Untuk mendapatkan kepercayaan publik dalam menyampaikan informasi diperlukan suatu strategi komunikasi.Adanya strategi komunikasi pelayanan publik yang mempertimbangkan pada aspek kebutuhan masyarakat dapat 
terbangun mutual trust di dalam pelayanan publik (Kusumadinata \& Fitriah, 2017). Untuk dapat mengimplementasi strategi komunikasi humas pada lembaga pemerintahan di era milenial yaitu seorang Humas harus dapat memegang prinsip transparansi, akuntabel, edukasi, dan responsif. Transparansi diartikan sebagai terbuka mengenai latar belakang, implementasi, serta perkembangan/perubahan kebijakan kepada masyarakat disampaikan secara berkala; akuntabel yaitu penjelasan terhadap publik yang dilakukan berdasarkan data-data valid internal dan eksternal; edukasi yaitu memberikan pemahaman mengenai posisi dan peran lembaga pemerintah bagi kepentingan publik; dan responsif yaitu tanggap terhadap keinginan publik untuk mendapatkan informasi dan tanggap untuk menjawab keluhan atas layanan yang diberikan ke publik. Keempat prinsip dalam melaksanakan strategi komunikasi tersebut diharapkan dapat menjadikan terwujudnya kepercayaan publik pada lembaga pemerintahan.

Maka dari itu, peran strategis di era digital bagi lembaga humas pemerintahan harus dapat menghadirkan seorang humas yang multitalenta. Artinya, kualifikasi dasar seorang humas merupakan ahli komunikasi dan dapat mengoperasionalisasikan kegiatan-kegiatan yang terkait dengan teknologi informasi yang mendukung aspek marketing yang dapat menjual branding personal, produk, dan lembaga di benak pikiran masyarakat. Sehingga secara praktis, bedanya peran humas era digital dengan konvensional adalah dalam hal penggunaan medium dan pendekatan metode komunikasi.

Keberadaan humas yang adaptif di lembaga pemerintahan akan memberikan peluang yang besar untuk dapat membangun citra dan reputasi lembaga menuju ke arah yang lebih profesional. Selama ini humas pemerintah sering mendapatkan sematan sebagai bagian atau bidang "buangan", tidak produktif, menghabiskan anggaran, tukang kliping, penerima tamu, dan lain sebagainya. Padahal, Humas merupakan ujung tombak pengelolaan informasi dari suatu organisasi. Hal ini sebagaimana tercantum dalam Peraturan Menpan No.12 Tahun 2007 tentang Pedoman Umum Hubungan Masyarakat di Lingkungan Instansi Pemerintah yang menyebutkan bahwa humas pemerintah adalah aktifitas lembaga atau individu, yang melakukan fungsi manajemen dalam bidang komunikasi dan informasi kepada publik pemangku kepentingan dan sebaliknya. Disini artinya humas dibutuhkan sebagai perwakilan pemerintah untuk berinteraksi dengan publiknya (Ristanto, 2014).

Unsur opini publik menjadi sangat penting bagi lembaga pemerintah dalam rangka untuk mengetahui posisi kinerja programpemerintahan 
di masyarakat. Kegiatan opini publik bisa tercapai apabila keadaan kegiatan komunikasi dan informasi dari sistem pemerintah yang bersifat demokrasi. Artinya sistem demokrasi dalam pemerintahan dapat mewujudkan keterbukaan informasi menuju good governenace yang dapat disampaikan, mudah diakses, dan didokumentasikan oleh publik. Keberadaan humas pemerintah yang berperan untuk menjembatani kepentingan pemerintah dan masyarakat berfungsi guna memperoleh pengertian, kepercayaan, dan dukungan dari masyarakat melalui penyelenggaraan di bidang informasi publik. Untuk mendapatkan informasi publik yang valid, Bagian Humas harus dapat berkolaborasi dengan Satuan Perangkat Kerja Daerah (SKPD) dalam mendiseminasikan dan pelayanan informasi yang dapat "menenangkan" pemerintah dalam membangun programprogram kebijakannya.

Menurut Kepala Dinas Kominfo Jabar bahwa ditengah kemajuan teknologi informasi dan komunikasi, layanan informasi publik tidak dapat bekerja sendirian. Hal ini terungkap dalam hasil wawancara yang menyebutkan bahwa:

"Sebagai instansi Pemerintah, Diskominfo sedang mencoba mengimplementasikan peraturan pemerintah tentang keterbukaan informasi dan kenapa bagian humas harus benar-benar mengelola perangkat teknologi informasi secara terintegrasi, seperti portal website pemprov, Jabar Saber Hoaks, dan Jabar Command Center. Aspek teknologi menjadi sangat penting dalam menunjang kegiatan penyebaran informasi publik yang dibantu oleh tim adhoc yang khusus mengelola konten".

Keterlibatan publik dalam keterbukaan informasi publik berfungsi untuk membangun antara pemerintah dan warga masyarakat yang tidak hanya sekedar sebatas pertukaran informasi saja, melainkan dalam upaya mendukung dan partisipasi masyarakat yang dapat mempengaruhi pengambilan keputusan/ kebijakan pemerintah. Mengingat pentingnya keterbukaan informasipublik, humas pemerintah harus dapat memperkuat penyebaran informasi berita melalui berbagai kanal komunikasi resmi pemerintahan dalam upaya meminimalisir potensi berita bohong/palsu, ujaran kebencian, dan fitnah yang dapat mengganggu pada proses pembangunan.

Maka dari itu, manajemen yang dibutuhkan pada era keterbukaan informasi publik bagi lembaga pemerintah adalah pola kinerja humas yang menggunakan dan memanfaatkan aspekaspek manajemen perencanaan, pelaksanaan, dan evaluasi yang ditunjang secara teknologi. Humas sebagai bagian dari ekosistem koalisi manajemen puncak perlu mempertahankan kompetensi dan keterampilan baru dalam pengelolaan perangkat informasi digital. Keberadaan teknologi dan dunia digital tidak harus dilihat sebagai ancaman, tetapi justru sebagai peluang yang dapat mendorong produktivitas dan efisiensi ke level baru. 
Kondisi seperti itulah yang seharusnya humas pemerintahan responsif terhadap perkembangan ICT.

Terkait dengan perkembangan revolusi industri di era big data yang tidak hanya membuat bidang teknologi saja, namun juga bidang lainnya, seperti hukum, ekonomi, dan sosial telah tercerabut dari dasarnya untuk bisa berkembang dan menyesuaikan diri. Untuk mengatasi disrupsi, maka diperlukan revitalisasi peran ilmu sosial humaniora sebagai dasar acuan pengembangan teknologi agar teknologi tidak tercerabut dari nilai-nilai kemanusiaan (Prasetyo \& Trisyanti, 2018). Dalam implementasinya, jumlah informasi yang terus diproduksi setiap detik dan tak terhingga mengenai sebaran informasi yang sudah pada level derajat tsunami informasi. Banyaknya sebaran informasi maka diperlukan langkah preventif melalui literasi digital untuk menanggulangi informasi palsu di era posttruth, dengan mengetahui tanda-tanda informasi atau berita palsu, prosedur verifikasi informasi, hingga menindaklanjuti informasi yang masuk kategori hoax (Sabrina, 2018). Di sisi lain, masyarakat berhak menyampaikan keluhan, saran, atau kritik tentang penyelenggaraan negara yang dianggap tidak sesuai dengan peraturan perundang-undangan yang berlaku (Setiaman et al., 2013) dan wajib dijawab oleh lembaga layanan informasi publik dalam upaya mewujudkan open government.

Saat ini dan ke depan, eksistensi humas pemerintah menjadi sangat "seksi" dituntut untuk dapat mengaktualisasikan perannya di tengah dinamika masyarakat dan paparan teknologi informasi yang sangat cepat berubah. Bermodalkan situasi masyarakat yang sudah banyak menggunakan teknologi informasi, humas pemerintah kini harus sudah beradaptasi dengan menggunakan pola komunikasi simetris yang berbasis media baru yang sering dipakai oleh publik.

Keadaan situasi birokrasi lembaga pemerintahan yang "kaku" dapat menghalangi kerja profesional Humas untuk dapat berkreasi lebih dalam rangka menciptakan suatu inovasi dan inspiratif dalam layanan informasi publik serta menampilkan pesan-pesan brand kelembagaan yang bercitra positif(Budhirianto, 2020). Maka dari itu, kegiatan kehumasan di lembaga pemerintah bukan hanya sekedar lembaga penyebar informasi saja, tetapi harus terjadi sharing informasi, pertukaran informasi, atau komunikasi dua arah, sehingga humas merupakan bagian dari pengambilan keputusan pimpinan pemerintah (top management).

Sikap humas pemerintah dalam keterbukaan informasi pada media digital perlu dimaknai secara serius. Kehadiran media digital yang kini menjadi saluran utama komunikasi baik di lembaga maupun masyarakat telah membawa 
dampak tersendiri sebagai saluran komunikasi baru dalam berhubungan dengan publiknya (Pienrasmi, 2015). Sebagai praktisi humas yang ada di lembaga pemerintahan maka perlu mengembangkan sebuah paradigma baru yaitu dari konsep relasi ke kolaborasi. Adanya saluran komunikasi media digital, sesungguhnya dapat menjadi peluang dan tantangan bagi humas pemerintah untuk dapat mengoptimalisasikan isi pesan-pesan pemerintah terkait dengan program dan kebijakan pembangunan yang ingin disampaikan kepada publiknya. Apalagi keberadaan lembaga pemerintahan yang selalu menjadi topik pembicaraan yang "seksi" bagi kalangan praktisi media massa sebagai sumber informasi terkait implementasi kebijakankebijakan pemerintah yang dicanangkan. Maka dari itu, penyampaian informasi kebijakan yang berorientasi pada pelayanan publik sangat ditunggu-tunggu oleh berbagai pihak kepentingan dalam rangka "mengamankan" tujuan yang dicapai dalam isi kebijakan tersebut.

Seiring dengan perkembangan teknologi informasi yang mendukung pada pelaksanaan keterbukaan informasi publik dalam penyelenggaraan negara atau pemerintahan merupakan bagian dari perwujudan tata kelola pemerintahan yang baik dan bagian utama dalam memperoleh jaminan kepastian hukum terhadap hak masyarakat dalam memperoleh jenis layanan informasi yang dibutuhkan serta ambil bagian untuk ikut terlibat mengawasi penyelenggaraan negara atau pemerintah melalui informasi yang didapatkan. Saat ini kebijakan pemerintah yang diinformasikan sering tersebar lebih dahulu di media sosial dibandingkan di media massa. Hal ini tentunya membutuhkan daya selektifitas yang tinggi dari humas pemerintah untuk dapat menyaring informasi yang sudah tersebar di media sosial tersebut agar dapat terjaganya citra dan reputasi lembaga. Penyampaian informasi publik ini seiring dengan amanat UU KIP yang harus dilaksanakan oleh setiap lembaga yang dibiayai oleh negara ataupun yang bersumber dari swadaya publik. Sebagaimana hal ini diungkapkan oleh Ijang Faisal selaku Ketua Komisi Informasi Daerah Jawa Barat periode 2019 - 2021 yang menyebutkan bahwa:

"Setiap badan publik yang ada di Indonesia harus dapat melaksanakan keterbukaan informasi publik sesuai UU No. 14 tahun 2008 dalam rangka mewujudkan standar layanan informasi publik yang efektif, efisien, akuntabel dan profesional".

Artinya di era dinamika teknologi informasi saat ini yang berbasiskan pada kecepatan penyebaran informasi, keterbukaan atau transparansi menjadi suatu keharusan diimplementasikan oleh lembaga atau badan publik yang dimulai dari orang nomor satu di badan publik tersebut. Kondisi ini menjadi peluang dan tantangan ke depan bagi humas pemerintahan untuk dapat mengelola informasi 
secara baik dan profesional dengan tetap terjaga nilai-nilai citra dan reputasi lembaga. Tempat keluar dan masuknya informasi di suatu lembaga yang bersifat satu pintu informasi merupakan bagian dari peran fasilitator komunikasi pada lembaga humas (Siswanto \& Abraham, 2016).

Ada kalanya isi informasi kebijakan yang tersampaikan di media digital dikutip dan dijadikan berita oleh sebagian media massa untuk mendapatkan "angle" berita di benak masyarakat. Hal ini tentu menjadi keuntungan maupun kerugian tersendiri bagi pihak humas dalam mendesiminasikan informasi publik. Pada dasarnya, tugas dan fungsi humas pemerintahan berdasarkan Permendagri No.13 Tahun 2011 salah satunya adalah lembaga kehumasan yang terkait dengan informasi mempunyai tugas untuk dapat memberikan informasi kepada masyarakat terkait dengan kebijakan, program dan kegiatan pemerintah; mengelola informasi yang akan dikomunikasikan kepada masyarakat secara cepat, tepat, akurat, proporsional dan menarik yang selaras dengan dinamika masyarakat; menyampaikan informasi kebijakan, program dan kegiatan pemerintah secara lengkap, utuh, tepat, dan benar kepada masyarakat. Sedangkan fungsi humas pemerintahan yang terkait dengan informasi adalah melakukan pengembangan analisa media dan informasi \& pelayanan dan penyebarluasan informasi dan dokumentasi. Aktivitas humas pemerintah mencakup urusan publik, informasi publik, dan komunikasi publik serta terkadang peran humas pemerintah bergeser menjadi politis. Sering kali bagian vital pemerintahan ini dijuluki sebagai "humas saja", "anggaran publisitas", "mesin propaganda", atau "dokter keliling". Padahal pekerjaan humas merupakan pekerjaan yang menentukan kesuksesan atau kegagalan dari pemerintahan dari sisi pelayanan informasi dan komunikasi publik (Yazid, 2015).

Sikap humas pemerintah terkait dengan penyebaran informasi publik di media sosial harus tetap berpegang pada Permendagri No. 13 Tahun 2011 tersebut untuk dapat menjaga harmonisasi pelayanan informasi antara internal-eksternal lembaga pemerintah dengan kelompok kepentingan terutama masyarakat. Hal ini menandakan bahwa perubahan wajah humas pemerintah dari yang cenderung 'tradisional' menjadi lebih 'modern' (Sani et al., 2020). Di sisi lain, adanya Undang-undang KIP ini telah menjadikan fungsi dan tugas humas dapat terintegrasi dengan Pejabat Pengelola Informasi dan Dokumentasi dalam melayani fungsi pelayanan informasi publik di lembaga pemerintahan. Ketersediaan media penyampai secara online melalui website maupun penyampaian informasi melalui media cetak dan eletronik (televisi lokal) serta maka terdapat kemudahan dalam mengakses informasi dalam penyelenggaraan kegiatan pemerintahan 


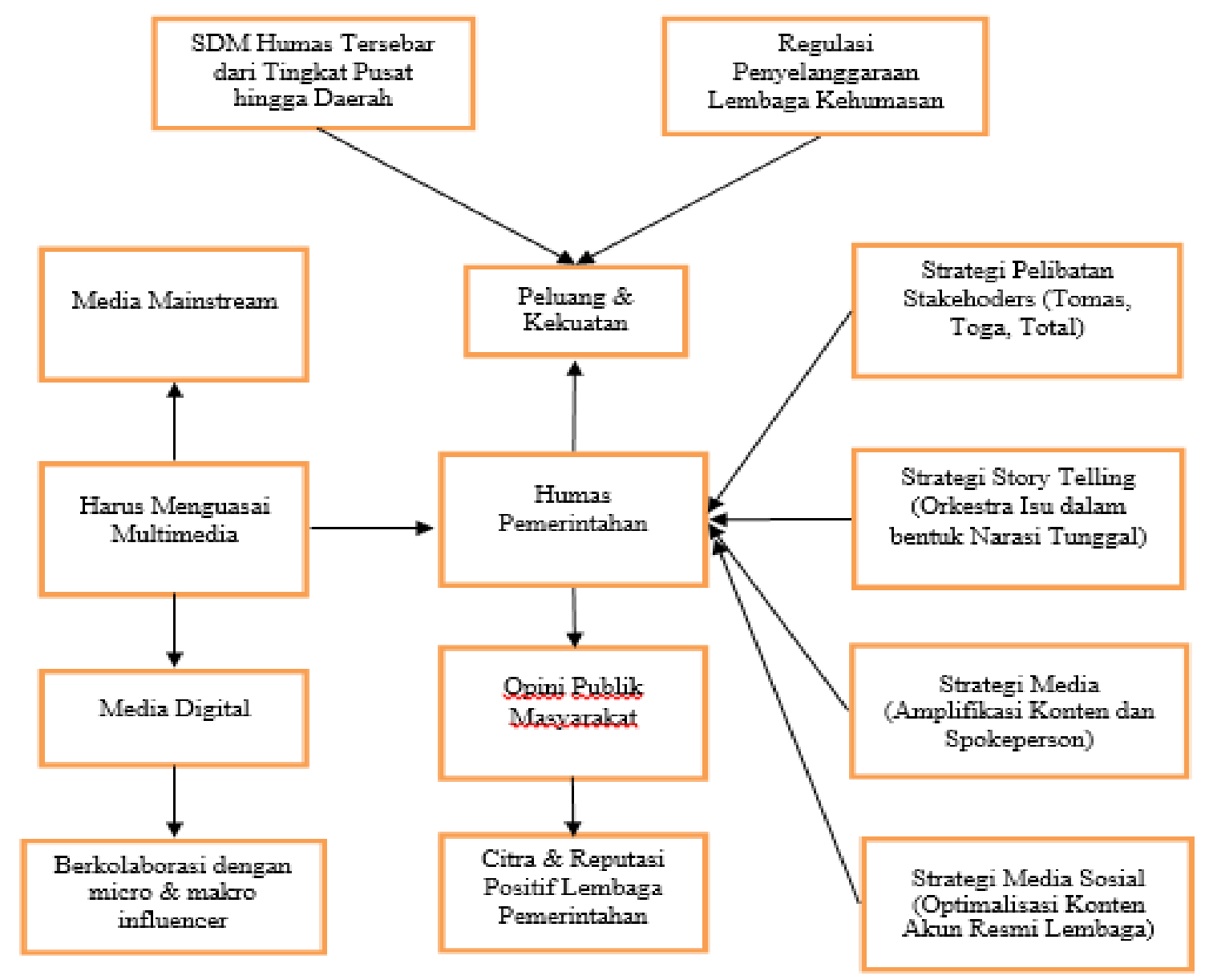

\section{Gambar 1 Mekanisme Analisis Strategi Humas Pemerintahan}

Sumber: Hasil Penelitian, 2019-2021

(Hereyanto, 2017).

Untuk menciptakan keberadaan Humas di lembaga pemerintahan yang profesional diantaranya harus bisa membuka akses komunikasi dua arah dan timbal balik antara pemerintah dan publiknya serta Humas harus bisa menyerap berbagai informasi dan aspirasi publik.KemampuankompetensiHumaslembaga pemerintahan dalam mengolah informasi dan komunikasi dari publiknya dapat dijadikan sebagai bahan masukan bagi pemerintah dalam melaksanakan peyelenggaraan pemerintahan merupakan hasil dari jawaban atas kebutuhan dan tuntutan publik secara berimbang, terbuka, dan dapat dipertanggungjawabkan dalam merealisasikan kebutuhan dasar publik. Selain itu, humas harus berani tampil dan penuh percaya diri dan memegang teguh pada aspek etika profesi dalam menyampaikan suatu informasi publik agar tidak bersifat "liar" ketika 
berada di masyarakat.

Mekanisme analisis terhadap strategi humas pemerintahan di era milenial, dapat dilihat pada gambar 1 .

\section{SIMPULAN}

Kekuatan dan peluang dari humas pemerintah dalam menyikapi keterbukaan informasi publik di era milenial yaitu meliputi sinergi komunikasi digital antarlembaga sektor pemerintahan dan publik dan adanya regulasi yang menjamin keberlanjutan mengenai tata kelola kelembagaan Humas menuju profesional dan tercapainya good governance. Sedangkan hambatan dan ancaman bagi humas pemerintah di era milenial meliputi kapasitas SDM yang belum ajeg, anggaran kegiatan yang terbatas, sarana dan prasarana yang minim, dan kewenangan peran dan fungsi Humas yang masih berbeda-beda pada level pemerintahan pusat, provinsi, maupun kabupaten/kota.

Strategi yang dapat dilakukan oleh humas pemerintah untuk mengembangkan tata kelola informasi publik di era milenial ialah dengan mendorong pemanfaatan penggunaan model strategi pelibatan stakeholders, strategi story telling \& narasi tunggal (agenda setting), strategi optimalisasi media konvensional, dan strategi optimalisasi media digital \& media sosial untuk terciptanya positioning humas pemerintah yang strategis dan kontributif bagi lembaga pemerintahan.

Saran dalam penelitian ini adalah sebaiknya lembaga humas pemerintah pusat, provinsi, dan kabupaten/kota dapat mengkolaborasikan berbagai strategi komunikasi publik dalam upaya mengoptimalkan pelayanan informasi dan komunikasi yang berbasiskan pada aplikasi digital yang sesuai dengan kebutuhan lembaga dan publik era milenial dengan menampilkan isi sajian informasi yang bermuatan narasi tunggal mengenai kebijakan maupun program pembangunan pemerintah pusat dan daerah yang sudah, sedang, maupun akan dilaksanakan.

\section{DAFTAR PUSTAKA}

Arief, N. Nurlaela, \& Saputra, M. A. A. (2019). Kompetensi baru public relations (PR) pada era artificial intelligence. Jurnal Sistem Cerdas, 2(1), 1-12. https://doi. org/10.37396/jsc.v2i1.19

Arief, N. Nurlalela. (2019). Public relations in the era of artificial intelligence: bagaimana big data dan AI merevolusi dunia PR. PT Simbiosa Rekatama Media.

Azhary, S. (2020). Strategi pemeliharaan relasional dalam kegiatan public relations online badan publik di Indonesia. PRofesi Humas Jurnal Ilmiah Ilmu Hubungan Masyarakat, 4(2), 193. https://doi. org/10.24198/prh.v4i2.19558

Budhirianto, S.(2020). Transformasi pendekatan komunikasi publik pada humas pemerintah di era digital. In C. S. D. Takariani, D. Praditya, \& Lia Puspitasari (Eds.), Media, Komunikasi, Teknologi Informasi dan Komunikasi (1st ed.). Penerbit Halima. 
Cangara, H. (2014). Perencanaan\& Strategi Komunikasi. Raja Grafindo Persada.

Gasing, S. S., \& Suryanto. (2016). Public Relation. Yogyakarta: Andi.

Hartini, T. (2019). Upaya Perhumas Dalam Meningkatkan Kompetensi Public Relations. Makna: Jurnal Kajian Komunikasi, 4(1), 31-57. http://jurnal. unismabekasi.ac.id/index.php/makna/ article/view/1671

Herdiana, D., \& Khoiruddin. (2016). Peran dan strategi humas dalam pembentukan citra perguruan tinggi islam. ANIDA, 15(2), 317-338.

Hereyanto.(2017). Analisis capaian keterbukaan informasi publik pada Pemerintah Kota Banjarmasin. MetaCommunication: Journal of Communciation Studies, 2(2), 38-52. https://doi.org/http://dx.doi. org/10.20527/mc.v2i2.4085

Inspirasi. (2019). Transformasi Humas dalam Era Revolusi 4.0. Bamboedoea, 1-2. http://bamboedoea.com/wp-content/ uploads/2019/03/Inspirasi-Edisi-20-8halaman-4.pdf

Iriantara, Y. (2019). Humas Pemerintah 4.0. Media Nusantara, 16(1), 13-26. http://ojs. uninus.ac.id/index.php/MediaNusantara/ article/view/630

Kartika, R. (2020, April). Mix - April-Mei 2020. pdf. PR Indonesia, 6-7.

Kriyantono, R. (2018). Peran manajerial dan teknisi humas lembaga pemerintah dan swasta. Aristo, 6(1), 1. https://doi. org/10.24269/ars.v6i1.760

Kusumadinata, A. A., \& Fitriah, M. (2017). Strategi Komunikasi Pelayanan Publik melalui Program Pos Pemberdayaan Keluarga. Jurnal ASPIKOM, 3(1), 225238. http://jurnalaspikom.org/index.php/ aspikom/article/view/130
Martinelli, D. K. (2012). The Practice of Government Public Relations. In $\mathrm{M}$. Lee, G. Neeley, \& K. Stewart (Eds.), The Practice of Government Public Relations (pp. 143-). Taylor \& Francis.

Meranti, \& Irwansyah. (2018). Transformasi dan kontribusi industri 4.0 pada stratejik kehumasan. Jurnal Teknologi Informasi Dan Komunikasi, 7(1), 27-36. https:// jurnal.kominfo.go.id/index.php/jtik/article/ view/1458

Muhajirin, \& Panorama, M. (2017). Pendekatan praktis metode penelitian kualitatif dan kuantitatif. Idea Press.

Pienrasmi, H. (2015). Pemanfaatan Social Media oleh Praktisi Public Relations di Yogyakarta. Jurnal Komunikasi, 9(2), 199210.

Pohan, H. A. (2019). Kepemimpinan di Era Milenial Ditinjau dari Aspek Komunikasi. Jurnal Komunikasi Islam Dan Kehumasan (JKPI), 3(2), 156-174. http://jurnal. radenfatah.ac.id/index.php/JKPI/article/ view/5645/2966

Prasetyo, B., \& Trisyanti, U. (2018). Revolusi Industri 4.0 dan Tantangan Perubahan Sosial. IPTEK Journal of Proceedings Series, 5(1), 22-27. https://doi. org/10.12962/j23546026.y2018i5.4417

Pujileksono, S. (2016). Metode penelitian komunikasi kualitatif. Kelompok Instrans Publishing.

Ristanto, T. (2014). Peran Humas Pemerintah Kota Balikpapan Dalam Mengimplementasikan Konsep Smart City Di Kota Balikpapan. Commonline Departemen Komunikasi, 4(1), 387-399. http://journal.unair.ac.id/downloadfullpapers-comm35b76ba2bdfull.pdf

Sabrina, A. R. (2018). Literasi digital sebagai upaya preventifmenaggulangi Hoax.Jurnal 
Communicare, 5(2), 31-46. https://doi.org/ https://doi.org/10.37535/101005220183

Sahlan, M., Septiani, E., \& Khadiq. (2016). Studi analisis indeks kepuasaan stakeholders terhadap pelayanan publik pada bagian humas UIN Sunan Kalijaga Yogyakarta. Profetik, 9(2), 15-24. http://ejournal. uin-suka.ac.id/isoshum/profetik/article/ view/092-02/1098

Sani, A., Hidayat, M., \& Sjafirah, N. A. (2020). Pemahaman petugas kehumasan Kementerian Dalam Negeri tentang peran Humas Pemerintah. PRofesi Humas, $4(2), 215$. https://doi.org/10.24198/prh. v4i2.23528

Sarosa, S. (2017). Penelitian kualitatif dasardasar. Jakarta: Indeks.

Setiaman, A., Sugiana, D., \& M, J. N. (2013). Implementasi Kebijakan Keterbukaan Informasi Publik. Jurnal Kajian Komunikasi, 1(2), 196-205. https://doi. org/10.24198/jkk.v1i2.6044

Siddiq, U., \& Choiri, M. M. (2019). Metode penelitian kualitatif di bidang pendidikan (A. Mujahidin (ed.)). CV. Nata Karya.

Siswanto, B. D. L., \& Abraham, F. Z. (2016). Peran Humas Pemerintah Sebagai
Fasilitator Komunikasi Pada Biro Humas Pemprov Kalimantan Selatan. Jurnal Penelitian Komunikasi, 19(1), 55-68. https://doi.org/10.20422/jpk.v19i1.64 Sugiyanto, D. R., Sumartias, S., Yulianita, N., \& Komala, L. (2016). Professional government public relations in indonesia: a review. Journal of Education and Social Sciences, 3(February), 53-60.

Sugiyono, \& Lestari, P. (2021). Metode penelitian komunikasi. Bandung: Alfabeta. Suharyanti, Widiastuti, T., \& Kania, D. (2012). Reformasi birokrasi pemerintah dan penerapan Excellence Theory. Jurnal Ilmu Komunikasi, 10(1), 53-68. https://doi.org/ https://doi.org/10.31315/jik.v10i1.86

Suherman, U. D. (2018). Analisis strategi pengembangan potensi wisata halal pada hotel syariah di Jawa Barat. CV. Sadari.

Theaker, A. (2004). Public relations handbook. Routledge Taylor \& Francis Group. https:// doi.org/10.1080/00022470.1962.10468057

Yazid, T. P. (2015). Implementasi Cyber Public Relations Melalui Pengelolaan Website Pemerintah. Jurnal Ilmu Komunikasi, 6(2), 160-173. https://jkms.ejournal.unri.ac.id/ index.php/JKMS/article/view/3345 